\title{
UNIVERSITYOF
}

FORWARD

THINKING

WESTMINSTER用

WestminsterResearch

http://www.westminster.ac.uk/westminsterresearch

The Turtle Garden: Tan Kah Kee's last spiritual world

Wang, C.

This is an Accepted Manuscript of an article published by Taylor \& Francis in the International Journal of Heritage Studies, doi: 10.1080/13527258.2016.1153494

Available online:

http://www.tandfonline.com/https://dx.doi.org/10.1080/13527258.2016.1153494

The WestminsterResearch online digital archive at the University of Westminster aims to make the research output of the University available to a wider audience. Copyright and Moral Rights remain with the authors and/or copyright owners.

Whilst further distribution of specific materials from within this archive is forbidden, you may freely distribute the URL of WestminsterResearch: ((http://westminsterresearch.wmin.ac.uk/)).

In case of abuse or copyright appearing without permission e-mail repository@westminster.ac.uk 
Accepted author manuscript version

\section{The Turtle Garden: Tan Kah Kee's last spiritual world}

Cangbai Wang

Department of Modern Languages and Cultures, University of Westminster, UK

c.wang6@westminster.ac.uk

\section{Introduction}

On 21 October 2014, the National History Museum of Overseas Chinese (NHMOC) was officially opened in Beijing, P. R. China (PRC). As China's first national museum exhibiting the subject of huaqiao ${ }^{1}$ (Overseas Chinese), NHMOC marks the peak of the huaqiao museum boom starting from the mid-1990s. Since then over 15 huaqiao museums have been constructed mostly in Guangdong and Fujian provinces, China's major qiaoxiang (the hometown of Overseas Chinese). China inherits a long history of overseas migration, and her current global influence is carried in significant measure by the continued migration of Chinese nationals to all parts of the globe. At a time when heritage is high on the agenda of China's economic and cultural policies, it is urgent to look at the intricate relationship between China's heritage discourse and its treatment of diasporic subjects, an important yet largely overlooked aspect in the research of Chinese heritage.

This paper is an attempt to address this important but under-studied issue through a case study of Tan Kah Kee (also known as Chen Jiageng ${ }^{2}$ in mainland China), the first individual with Overseas Chinese background who engaged with museum construction in the PRC. Tan built, from 1956 to 1959, the Huaqiao Bowuyuan (Overseas Chinese Museum) on Xiamen Island following the fashion of civic museums for transmitting Western-originated museology to China ${ }^{3}$. Almost simultaneously, from 
1951 to 1961, be built an open-air museum called Ao Yuan (the Turtle Garden) at the village of Jimei, Xiamen. Tan was also the founder of Xiamen University and the indisputable leader of the Overseas Chinese in Southeast Asia in their moral and financial support of China's war of resistance against Japan. He was hailed by Mao Zedong as 'the banner of Overseas Chinese and the glory of Chinese nation' (Tan 1993, 486) for his contribution to China's anti-Japanese war. It is perhaps not a coincidence that the 2014 opening of NHMOC was chosen by the Chinese authorities for the $140^{\text {th }}$ anniversary of the birth of Tan Kah Kee, suggesting that the current tide of huaqiao museum construction is a revival of Overseas Chinese nationalism embodied by Tan. Given the significant role of Tan in China's huaqiao museum development and discourse, it is essential to trace the huaqiao museum construction to the time of Tan Kah Kee to unveil the intricate relationship between heritage-making and diasporic subjectivities from the very beginning of their entanglement. Specifically, this study is driven by several questions. What motivated Tan and the Overseas Chinese to participate in museum construction in the juncture of China's transition from a semicolonised country to a communist nation-state? How did they contest and negotiate with the revolutionary discourse, or what Smith $(2006$, 6) calls Authorised Heritage Discourse (AHD) as defined in Maoist China? And furthermore, what can this case study tell us about the value of heritage-making by people 'outside' the official realm of heritage discourse for democratic 'world-making' (Simon and Ashley 2010, 249) beyond Chinese context?

Keeping these questions in mind, this paper focuses on the Turtle Garden as an analytical lens to examine Tan Kah Kee's museum outlook and practice, and through which to arrive at a deeper and broader understanding of diasporic imaginings of heritage in relation to identities, mobilities and nationhood. The garden was built on a 
turtle-shaped islet. It covers an area of 9,000 square meters, in the centre of which stands the Jimei Liberation Monument that Tan built to commemorate the liberation of his hometown by communist troops from the occupation of the GMD (Chinese Nationalist Party) forces. Tan was buried in the garden after his death in 1961, coinciding with completion of the construction of the garden. Unlike the Overseas Chinese Museum, which was situated in a prominent location of the city area, the Turtle Garden was built in a remote village on the outskirt of Xiamen. And while the Overseas Chinese Museum has been widely researched by Chinese scholars as evidence of Tan's contribution to China's museum construction as part of educational modernisation (Liu 2014; Huang 2014), the Turtle Garden has received scant academic attention. By foregrounding the Turtle Garden as the object for analysis, in relation to Tan's life experience as a migrant and in the context of 1950s China, the author argues that the garden is as important as the Overseas Chinese Museum to our understanding of Tan as a person and the diasporic museum outlook he represented. Built in combination of the Western notion of civic museums and Chinese poetics of gardening, the garden is conceptualised here as a postcolonial 'carnivalesque' space (Bakhtin 1984) characterised by the juxtaposition and negotiation of conflicting ideas - old and new, modern and traditional, Confucian and revolutionary, life and death - each demanding equal dialogic status. This unavoidably produces chaos and ambivalence between personal experience, emotional/ancestral longings and political realities, unleashing an innovative and liberating power to articulate a diasporic imagining of Chinese identities and a cultural representation of Chinese nation from the 'outside'. The Turtle Garden is therefore more than a museum; it is a miniaturised natural landscapes symbolising Tan's spiritual world as a diasporic Chinese. 
This article firstly unearths the formation of what is called a diasporic museum outlook by contextualising Tan's museum practice in his life experience as a Chinese migrant, and then examines the construction of the Turtle Garden against the political reality of 1950s China. The main part of the article is given to interpretations of the garden as a cultural landscape drawing on Bakhtin's notion of 'carnivalesque'. The analysis demonstrates the highly complex and sometimes conflicting museum outlooks of Tan, and brings our attention to valuable but largely unknown heritage-making outside the highly centralised and monolithic heritage discourses of the Chinese Communist Party (CCP) in both the Maoist era and post-socialist China.

\section{The making of a diasporic museum outlook}

Shortly after the founding of the PRC, the CCP constructed a number of monumental buildings in Beijing to mark the start of this communist regime. These included the Great Hall of the People, the National Museum of Chinese Revolution, the National Museum of Chinese History, and the Monument to the People's Heroes. Built right on Tiananmen Square, the very symbol of China's political centre, these gigantic buildings spoke loudly an authoritative discourse that defined heritage, and in fact almost every single aspect of people's life, in revolutionary terms. Under this revolutionary discourse, museums were seen as a political tool to indoctrinate communist ideology and promote pro-CCP patriotic sentiments among the masses. This discourse had dominated the CCP's works on heritage throughout Maoist era and remained influential in the post-

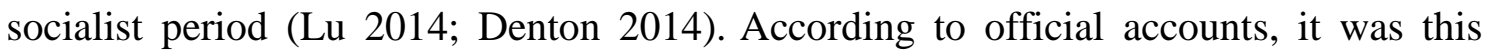
revolutionary discourse that inspired Tan to build museums in Xiamen as a way to demonstrate his loyalty and devotion to socialist China (NPPCC 1984, 287-289; Tan 2007). 
A careful reading of the Turtle Garden, however, suggests something more complicated. On the frontage of Tan's mausoleum is inscribed the name of the garden. Underneath the name are three Chinese characters: bo wu guan (museum outlook) and a Chinese antithetical couplet, written by Tan himself, which reads (author's translation), 'a genuine and comprehensive museum outlook is never constrained by the physical size of a small island (真大观莫嫌小岛); new functions and forms of a museum stem from its re-configuration of past heritages and traditions' (有旧殖乃展新型). Tan's museum outlook is explored below through three interrelated points: 'a hybrid cosmology', a 'postcolonial gaze' and a 'globalistic stance'. What propelled Tan to engage with museums and the ways he did it reflected, first, a hybrid worldview based on his bodily encounter with the Western modernity as a Chinese migrant from rural China in British Malaya; second, a postcolonial vision of the relationship between museum-building and nation-building that Tan's experience under British colonialism gave him; and third, a globalistic stance on China's nation-building project from his standing as champion of Overseas Chinese nationalism.

\section{A hybrid cosmology of a Chinese migrant in British Malaya}

Tan's engagement with museum-building needs to be understood firstly by taking into account his upbringing as a Chinese peasant and his life experience as a Chinese migrant in Singapore, then the centre of British Empire in the Far East. Tan was born in Jimei, Xiamen, Fujian province in 1874 . He received basic Chinese education mainly on Confucian classics through private tutoring at his hometown. At the age of 17 , he joined his father and his uncle in Singapore, then part of British Malaya under the Government of Strait Settlements, working for the family business in rice trading. He launched his own businesses in pineapples then rubber after his father passed away. By the 1920s he 
had become one of the most affluent Chinese businessmen in Southeast Asia and a respectable leader and a philanthropist in Overseas Chinese communities (Yong 1987; Chen and Hong 2003). He devoted most of his earnings to fund Jimei schools and Xiamen University and maintained their operations for many years (Wang and Yu 1981, 33-45; Tan 1993, 31). His prestige reached its peak when he was elected chairman of the Southseas China Relief Fund Union (SCRFU) in 1937, the largest and most successful fund-raising body in Overseas Chinese communities to support China's war of resistance against Japan. In 1940, Tan led an SCRFU mission to China where he visited Chongqing, China's wartime capital and Yan'an where the Communist headquarters sat. He was disappointed by the sweeping corruption and decadence in Chongqing and areas under the rule of the Nationalist government. By contrast, he was impressed by the high fighting spirit of Communist troops and the New Democratic government he saw at Yan'an. By the time he had completed the mission and returned to Singapore, he had become an admirer of Chinese communist leader Mao Zedong and a public critic of the Nationalist government (Tan 1993, 127-383).

Despite his rural background, as a shrewd businessman in British Malaya he had been immersed in the Western socio-economic environments, which provided him with a new source of knowledge and values. Although unable to speak or read any English, Tan gained substantial understanding of Western modernity through his bodily encounter with British establishments in Singapore and through his reading of Chinese translations of English books and newspapers (Yong 1987, 201-208; Tan 1993, 479498). A careful reading of his published works, many of which were on the topic of Britain's modernisation projects in Singapore, unveils the genesis of his museum outlook. In a book he published on housing and hygiene, for example, Tan detailed the ways in which the British authorities transformed Singapore's housing system as part of 
modern urban planning, and how scientific management methods had greatly increased the city's standards of hygiene, and people's quality of life and life expectancy. Tan argued strongly that China should follow the footstep of British Singapore to get rid of backward attitudes and practices in social customs, heath care and education in order to progress into a modern society (Tan 1993).

In short, Tan on the one hand inherited from his own educational and cultural backgrounds a set of traditional values as the repertoire of his knowledge and moral guidance for his conduct. On the other hand, his cultural encounter with the Western civilisation in British Malaya had given him new ideas and values. The combination of these two enabled Tan to embrace a highly hybrid cosmology on China's social development and nation-building, and this social-cultural hybridity constitutes a distinctive feature of what could be called his 'diasporic museum outlook'.

\section{A postcolonial gaze on museum-building and nation-building}

The 1940s witnessed the high tide of de-colonisation throughout Southeast Asia. Tan showed strong sympathy with the independence movement taking place in many European colonies in Southeast Asia, and lent his moral support publically to a number of nationalist leaders (Yong 1987, 354-355; Chen and Hong 2003, 430-431). Tan's natural connections with Southeast Asia and his Overseas Chinese background enabled him to see China not only as his home country but also one of the Asian nations seeking independence and dignity in the aftermath of the WWII. One major challenge faced by the colonised population in Asia was how to identify dis/continuities with the colonial past and reconfigure colonial relations in the 'deconstruction-reconstruction' of power relations (Hall 1996). Museums were one of the critical arenas where postcolonial conflicts and negotiations took place (Knell et al. 2011; Chambers et al. 2014). The 
‘Asian' outlook and postcolonial gaze Tan obtained from his experience under British colonialism explain to some extent why it was Tan, an 'outsider' to Chinese society and a man with limited school education, rather than domestic Chinese cultural elites, could show insight on museums as an important vehicle in China's nation-building project. Indeed, the construction of the Turtle Garden was directly influenced by Tan's experiences in British Singapore and his later visits of colonial museums in China ${ }^{4}$, discussed later in this article. While the Overseas Chinese Museum represents his effort to transmit Western museology to China, the Turtle Garden showcases his innovative attempt to re-configure social, cultural and political elements of the colonial past for the creation of an (imagined) new China in the postcolonial present.

\section{A globalistic stance on China's nation-building project}

Unlike the revolutionary museums that were built in Beijing and China's other political and economic centres with the aim to serve the domestic audience, Tan built his museums in Xiamen, a place situated at China's geographical and political periphery. Tan's decision to locate his museums here certainly had to do with the fact that he was originally from Xiamen. However, Tan also saw Xiamen, one of China's major sea ports, as an ideal place to express and promote his vision of a China that was open to different ideas and people from around the world (Tan 1956, 6). In Tan's view, China's links with the outside world were crucial for the success of China's modernisation project. Tan's naming of the indoor museum is another case in point. Instead of naming the museum after the place of Xiamen, Tan called it Huaqiao Bowuyuan (Overseas Chinese Museum), implying that although based in Xiamen, it was a collective effort and rallying point for globally-based Overseas Chinese from many different dialectic and regional groups. As such, the Overseas Chinese Museum was 'not only national, 
but also global' (Tan 1956, 7). It was the beacon of a transnational nation-building project that Tan had imagined and longed for. In short, from its inception Tan's museum-making endeavour was outward-looking, calling for the construction of a new Chinese nation in the global stage based on its openness to the outside world and constant supports from the Overseas Chinese.

\section{The Turtle Garden: Tan Kah Kee's final project}

1949 was a turning point in China's political history and also in Tan's personal life. In this year, he was invited by Mao to attend a meeting for the initial National People's Political Consultative Conference (NPPCC) as the representative of huaqiao and to participate in the ceremony of the founding of the PRC. Encouraged by the new face of China and convinced that Mao and the CCP would bring democracy, freedom and wealth to China, in 1950 and at the age of 77, he renounced his British citizenship and returned to settle in China permanently (NPPCC 1984, 20-21, 30-31; Yong 1987, 327335). Tan was given a number of glossy titles in the Central Government, including chairman of All-China Federation of the Returned Overseas Chinese, deputy chairman of NPPCC, member of the Standing Committee of Chinese People's Congress (CPC), and committee member of Chinese Central Government.

His enthusiasm for participating in the construction of a new China was soon dampened by waves of political campaigns starting from the early 1950s. By 1956 private business owners, industrialists, liberal intellectuals and outspoken supporters of democracy, once tolerated by the CCP's tongzhan (United Front) policy, had become the targets for class struggles and the objects for socialist education (Draguhn and Goodman 2002; Karl 2010). Little was known about the inner world of Tan when he went through these astonishing political chaos. Tan had serious disagreements with the 
CCP's policies in a number of areas (Chen and Hong 2003, 358-378). He was particularly baffled by the increasingly stigmatised status of the Overseas Chinese in Mao's nation-building project. When Chinese citizenship was no longer defined by Chinese descent but by class affiliations, the returned Overseas Chinese (he was one of them), once welcomed as 'red sons overseas', found themselves no longer qualified members of renmen (people) but 'the object for internal control' due to their suspicious overseas connections with the capitalist world (Wang 2013, 63-82). Under the increasingly radicalised political atmosphere, Tan was no longer able to voice his opinions freely and publically. He found himself excluded from China's political centre and was even deprived of the freedom to exit China again (Chen and Hong 2003, 385386). He was stuck in his own country as a lonely old man and a deeply frustrated patriot.

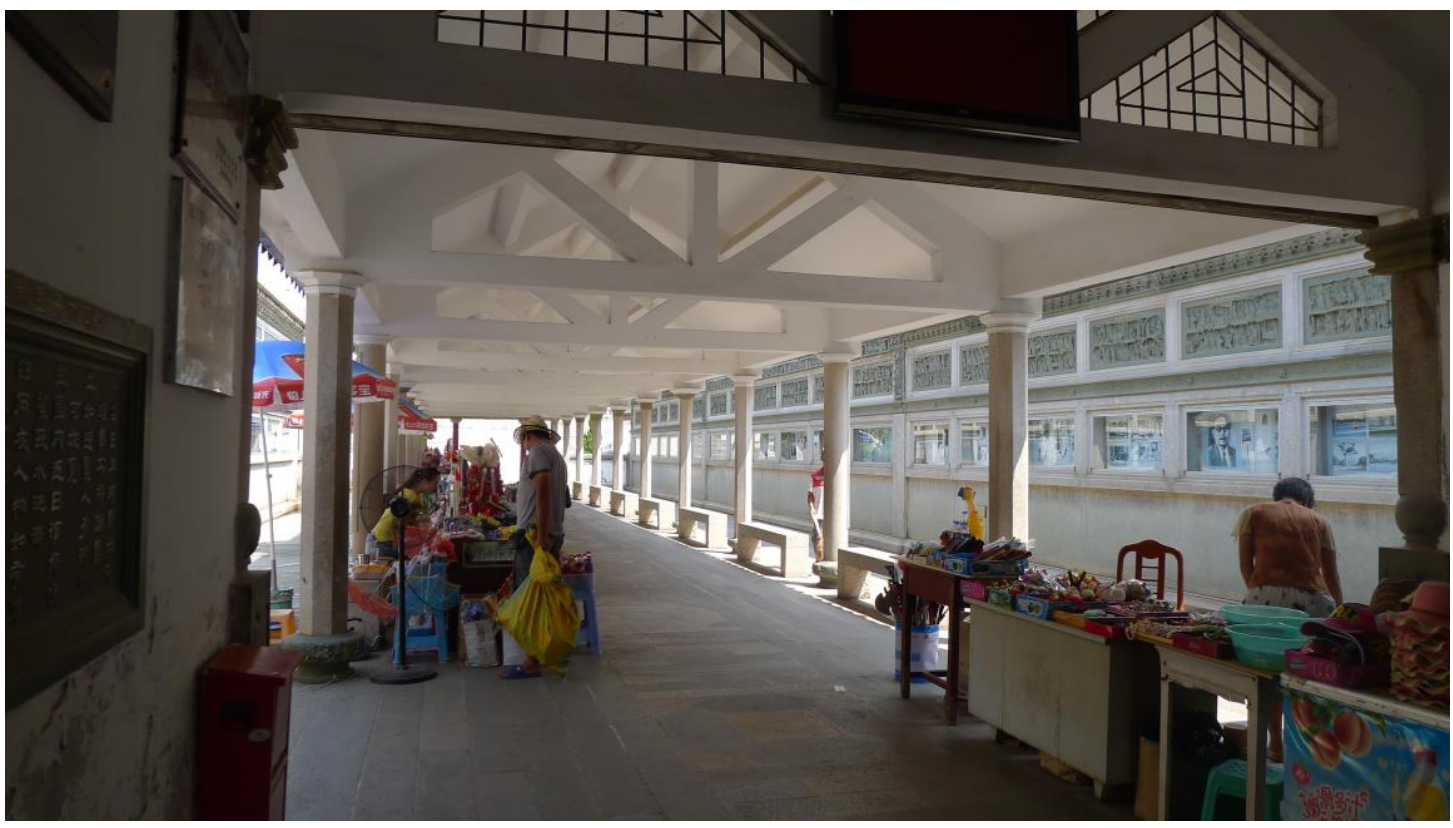

Figure 1: The roofed corridor with stone carvings displayed on its both sides (photo by author)

It was under these specific political circumstances that Tan retreated from Beijing to his home village Jimei, Xiamen, where he committed himself to the final 
project of his extraordinary life - the Turtle Garden ${ }^{5}$. There is a long history of gardening in Chinese culture, and one important tradition is the development of scholarofficial gardens where exiled or temporarily demoted officials could find retreat from troublesome political realities and fulfil their yearning of freedom in tranquillity (Keswick 2003, 51; Fang 2010, 20). By blending ornate architectures and natural elements, garden owners recreated miniaturised natural landscapes to symbolise their inner worlds (Ji 1988). In a similar fashion, Tan chose a secluded islet not far away from his old family house as the site for building his garden. The completed garden, named after the shape of the islet where it sits, is enclosed by walls and includes an assortment of buildings and pavilions, trees and flowers. A roofed corridor from the entrance, lined with galleries of stone carved images (figure 1), links to the other sites of the garden. The two main buildings of the garden, the Jimei Liberation Monument and Tan's mausoleum, stand at the centre of the garden. From here, visitors have a fine view of Xiamen Island in the distance, a 'borrowed scenery' (Chen 2002) that gives the illusion that the garden is bigger than it is. Water, 'the soul of all gardens' (Fang 2010, 102), also plays an important role here. The sea water around the islet serves as the natural boundary of the garden, and produces the infinity of space by integrating the natural landscape of sea. A distinctive feature of the garden is its extensive stone carvings that create a rich world of images as both artistic decoration and objects for display in their own right. It has a large number of calligraphies, couplets and slogans inscribed on stone lintels and stone pillars as well as stone-carved figures, events, maps, plants and animals displayed throughout the garden.

The Turtle Garden was raided by the Red Guards during the Cultural Revolution. Luckily, it survived the chaos with only a small number of stone carvings damaged ${ }^{6}$. After the death of Mao, in order to solicit the support of Overseas Chinese for China's 
economic reform and development, Deng Xiaoping, Mao's successor, restored the reputation of Overseas Chinese and reinstated Tan as a symbol of Overseas Chinese patriotism. The Garden was restored in the early 1980s, and in 1988 it was listed as one of China's key cultural relics by the State Council. Since the late 1990s, the garden has been further developed into a tourist spot as well as a base for patriotic education ${ }^{7}$.

\section{The Turtle Garden as a postcolonial 'carnivalesque space'}

It has been recognised that the Chinese garden is more than a place to display the cultivation and aesthetic taste of the garden owner, but represents the owner's spiritual world in microcosm (Keswick 2003, 85). In order to articulate the rich thoughts within its limited space, the Chinese garden 'restlessly oscillates between polar opposite, the yin and yang, the solid and void ...' (Jencks 2003, 214) 'where contradictions between Confucianism and Taoism, freedom and ritual, dream and reality, and academia and officialdom all elide into a unified whole' (Fang 2010, 52). The Turtle Garden exhibits the same logic in representing its owner's philosophical universe. To unpack the rich meanings of the Turtle Garden as embodiment of Tan's last spiritual world, the notion 'carnivalesque' (Bakhtin 1984) is a useful framing device. The concept carnivalesque is not new in the research of museums and heritage, and has been used to analyse narratives and processes of cultural conflict, resistance, negotiation and renewal (e.g. Walton 1998; Webb 2005; Dickinson et al 2005; McTavish 1998; Calvert 2012). Building upon Bakhtinian studies of museums and heritage in the Western context, this

article for the first time applies the concept 'carnivalesque' to a hermeneutic interpretation of Chinese gardens as kaleidoscopic cultural texts that would 'defeat any attempts at summary and understanding until we focus precisely on this superabundance and opposition' (Jencks 2003, 212). The usefulness of the notion carnvialesque for this 
study lies in its analytical attention to the dualistic and ambivalent imagery in meaningmaking processes, which is crucial for understanding the hidden meanings of the Turtle Garden, and the inherent 'outside-in' processes made by and for diaspora in redefining centrally-formed heritage discourses.

Bakhtin $(1999,126)$ argues that the carnivalesque world of the medieval times is a place where the contradiction and unification of the poles of change and crisis, birth and death, old and young, down and up, wisdom and stupidity, and so on, play out. The grotesque behaviour of the carnival creates a context where power relationships can be temporarily suspended, allowing suppressed voices to be heard. The 'carnival celebrated temporary liberation from the prevailing truth and from the established order; it marked the suspension of all hierarchical ranks, privileges, norms, and prohibitions' (Bakhtin 1984, 10). Furthermore, the carnival's ambivalent nature meant that it is not only about destruction as the locus for free representation of ideas, emotions and desires but also about regeneration, renewal and new birth. Through both processes, the carnivalesque practice 'builds its own world versus the official world, its own church versus the official church, its own state versus the official state' (88). Drawing upon Bakhtin's theories, the Turtle Garden can be seen as 'a zone of mixing and blending', 'a contested space' and 'a metaphor for imagined homecoming', through which the postcolonial nature of Tan's museum-making exercise is unveiled.

\section{The Turtle Garden as a zone of mixing and blending}

The Turtle Garden is a bewildering place where the mixing and blending of contradictory ideas, images and pursuits are demonstrated and celebrated loudly. The first Bakhtinian duality that jumps to the eyes of visitors is that of 'Communism' versus 'Confucianism'. The gallery on the northern side of the corridor consist of three 
sections. It starts with seven pieces of stone engraving that depict landmark events in the history of twentieth century Chinese revolution, such as the May Fourth Movement, the Long March and Mao's famous Yan'an talks on arts and literature. These revolutionary imageries are immediately followed by six pieces of stone carvings visualising the mythical prophesies by Zhuge Liang (181-234), the prime minister of the Kingdom of Shu and a man of superb wisdom in Chinese folklore (figure 2). The carvings validate Zhuge Liang's prediction of the rise and fall of Chinese dynasties, suggesting Mao and the CCP were preordained to lead China toward a brighter future in a harmonious world. Here, the legitimacy of the CCP is ironically validated by feudal 'superstitious' practices, the very target that the CCP would attack. The final section includes seven pieces picturing traditional Chinese moral stories instilling Confucian virtues such as loyalty, filial piety and righteousness. The gallery on the southern side of the porch has stone carvings of a selection of China's classic historical sagas and some recurrent themes of Chinese local operas and popular fictions. Overall, what the visitors see here is an unexpected but captivating juxtaposition of China's Confucian past and its revolutionary present and a brighter future. These poles are magically unified in Tan's personal interpretation of Zhuge Liang's prophesy of China's fate. It provides a sense of historical consistency, articulating Tan's historically-rooted and future-oriented contemplation about the fate of China as a civilisation, a culture and a modern nationstate. 


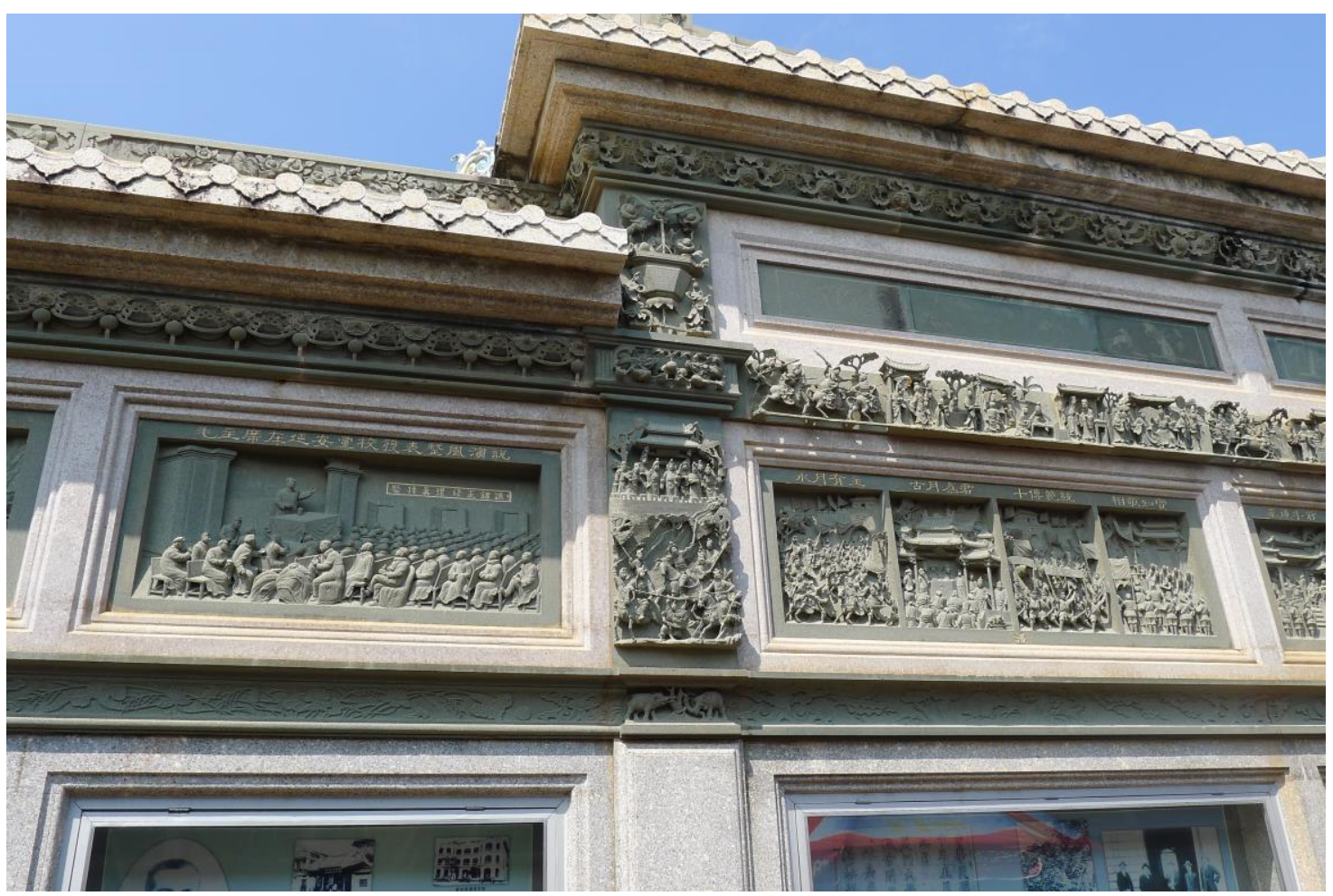

Figure 2: The juxtaposition of Mao's revolutionary events with Zhuge Liang's divine to predicate Chinese history (photo by author)

The second duality can perhaps be called 'modernity' versus 'tradition'. When visitors arrive at the central part of the garden, they are overwhelmed by abundant visual representations of a wide range of West-originated modern subjects, including biology, geography, botany, industrialisation, urbanisation, education and public health (figure 3). They are in sharp contrast to China's traditional moral stories and values illustrated on galleries along the corridor. The richest images of Western subjects are found on a folding-screen-shaped stone wall erected between the monument and the mausoleum. Stone sculptures on the front of the wall offer an encyclopaedic display of a large number of subjects, ranging from vegetables to factories, while scenes on the back contain sculptures of schools, hygiene, sports, and civilised custom and behaviour. The presentation of these modern subjects was meant to communicate a strong message to 
visitors, especially the younger generation, to live a modern life and ultimately achieve all-round moral, intellectual and physical development as Chinese citizens.

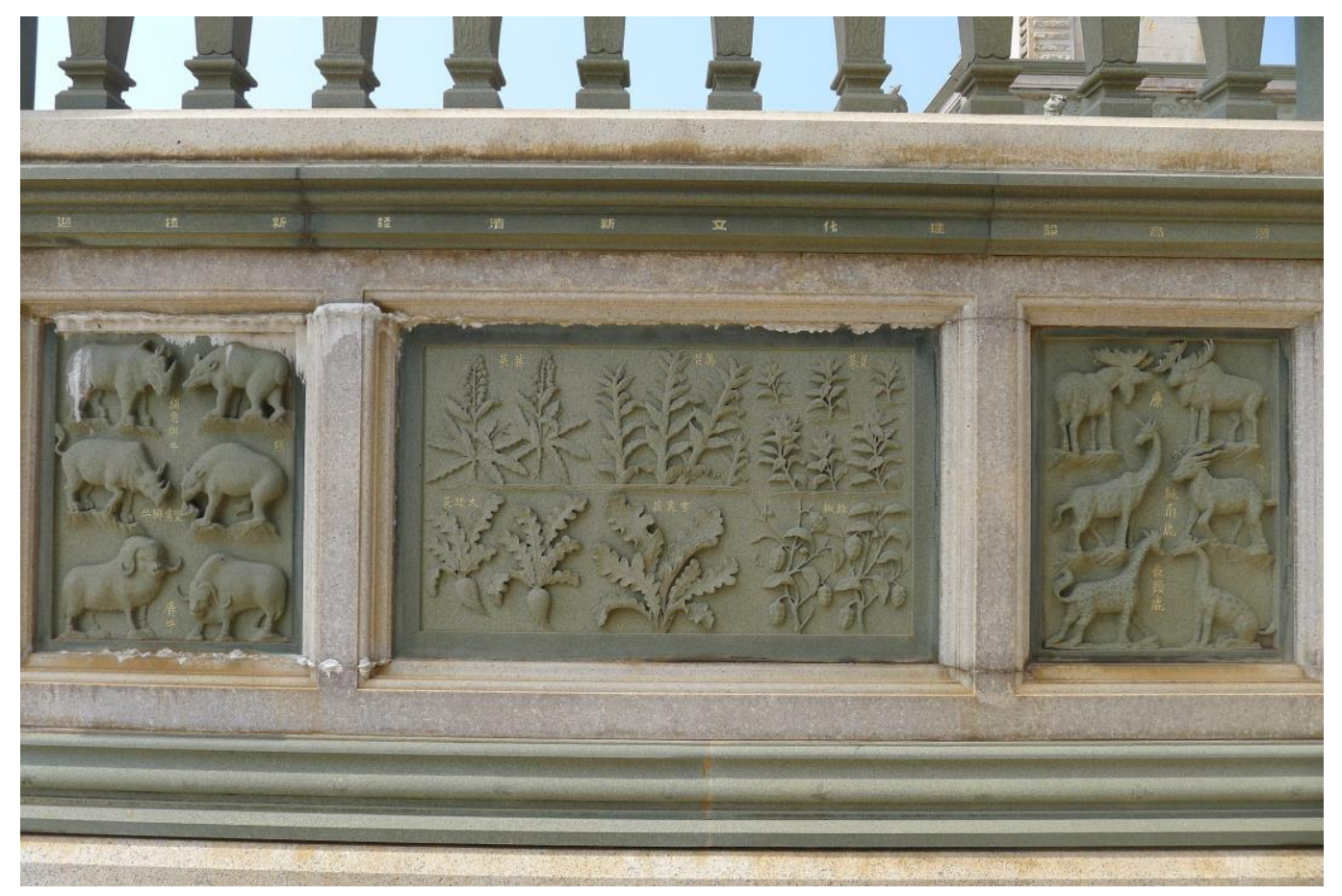

Figure 3: Stone carvings of plants and animals on the frames of monument podium (photo by author)

Thirdly, the Turtle Garden presents the contradiction and unification of 'life' and 'death'. Tan had not planned to be buried in the garden. But when he accidentally learned from a local stonemason that the islet had exceptional good fengshui (geomancy), he decide to build a tomb for himself inside the garden as he became increasingly ill (Chen and Hong 2003, 388). Today, a significant part of the garden is given to Tan's mausoleum, consisting of a stone tomb, a stone wall made in the shape of a Chinese folding screen and a pavilion in front of the tomb for people to rest when visiting the tomb. The Turtle Garden marks where Tan's life began and ended, symbolising the synthesis of his life and death as he searched for both his personal fate and the national future. 


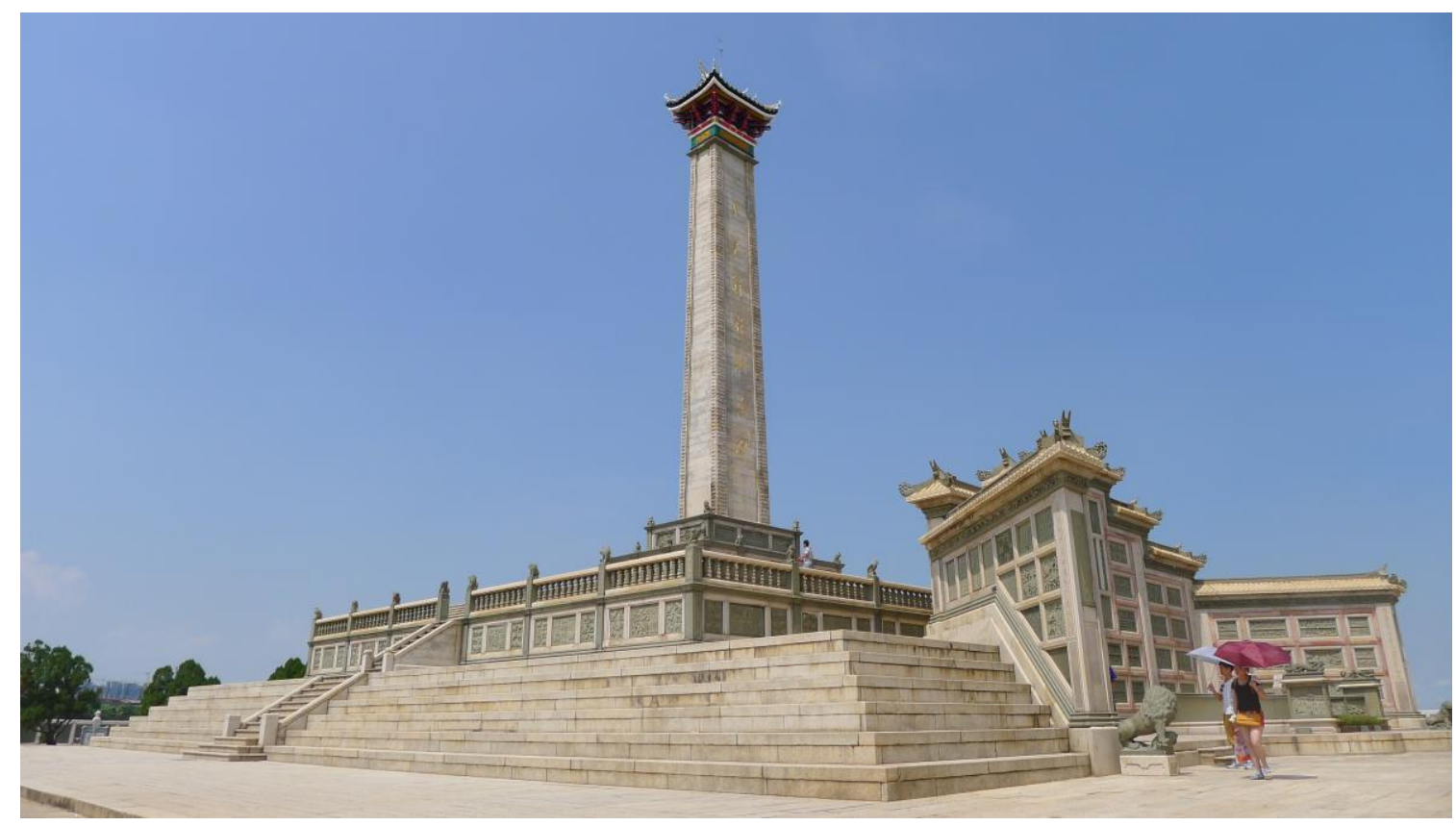

Figure 4: The Jimei Liberation Monument standing at the centre of the garden, adjoining Tan's Mausoleum. (photo by author)

Fourthly, the Turtle Garden is where 'private' space and 'political' space are juxtaposed and negotiated. Tan's tomb, the marker of his private space, is surrounded by 15 stone carvings recording in details key moments of his life journey, starting from his boyhood at Jimei, to his life and work in Singapore, his leading of SCRFU during WWII, up to his return to the PRC in 1950. By contrast, the Jimei Liberation Monument standing right next to his tomb (figure 4) signifies explicitly a national and political space. The name of the monument and the calligraphy of Mao is inscribed on the front, and Tan's biography and the origins of this monument is presented on the back. The tomb and monument are unmistakably separated but at the same time skilfully connected by the stone wall sitting between them. Individual and the national spaces are placed side by side, in competition and also in dialogue. As such, Tan's personal soulsearching as a diasporic Chinese, and his longing for a modern Chinese nation-state, are blended and powerfully presented through the spacing of the garden. 
Finally, although small in size, the Turtle Garden exhibits a much broader vision that goes beyond the place of Jimei and the space of China. On the back of the stone wall between the monument and the mausoleum are the map of Tongan county, Fujian province, Taiwan, and China. Engraved above these four is a map of the world. The display of these maps visualises the globalistic view of Tan, integrating domestic and international dimensions in this representation of his diasporic imagination about selfidentity and nationhood. What is equally interesting and important is the geographical placing of the Turtle Garden itself. Sitting on an islet connected with the mainland by an artificial causeway, it is detached from China's territory but at the same time linked to it. The two chief architectural features in the garden face the nanyang (Southern Ocean), where a large number of Overseas Chinese settled, rather than to the north where China's political centre sits. Taken together, this 'amphibious' positioning of the Turtle Garden and the orientation of its architecture symbolise a highly ambiguous cultural and political outside-inside in-betweeness of Tan and diasporic Chinese.

\section{The Turtle Garden as a contested space}

Like many other retuned Overseas Chinese who endured frustration and marginalisation during the Maoist era (Peterson 2012; Wang 2013, 63-82), Tan was also deeply disillusioned by the CCP's increasingly radicalised nation-building agenda. His frustration and resistance were particularly manifested in his treatment of textual inscriptions in the garden. For instance, one couplet reads (author's translation): 'Quietly studying museum knowledge' (静观博物志), and 'Singing the song of East is Red' (欢唱东方红). It is quite obvious that the 'Red East' refers to the New China or works a metaphor for Mao, the deified leader of Chinese communist revolution. The unusual combination of museum aesthetics with political consciousness revealed Tan's 
unvarnished yet confusing political pursuit as a frustrated nationalist. Another case in point was the way Tan dealt with the calligraphies of purged Chinese political figures. Tan had a number of calligraphies from China's political and cultural elites inscribed onto stone pillars or frames in the garden. They are mostly poems or phrases that hail friendship, extol natural landscape or glorify China's achievements of socialist construction. Among these calligraphies was one from Rao Shushi, a senior leader of the CCP who was removed by Mao from his post in 1955 due to alleged involvement in an anti-revolutionary conspiracy. Tan did not believe that Rao was a traitor. Although it was politically risky to have an anti-revolutionary's works displayed in public, Tan refused to remove Rao's calligraphy from his garden, and only agreed to rub out Rao's signature from the carving (Chen and Hong 2003, 396-398). This could perhaps be interpreted as a compromise in which the state had the upper hand as visitors could hardly identify the calligraphy by itself. However, considering the extremely difficult political situation at that time and the political courage needed to make this negotiation, it was a clear sign of resistance.

\section{The Turtle Garden as a metaphor of imagined homecoming}

Tan returned to his birthplace Jimei at the final stage of his life. Through his personal engagement with the garden construction, he tried to establish a sense of time and place about who he was, where he belonged and where he should go. The Turtle Garden displays a future-oriented sense of time: making connections between the past, the present and a promising yet uncertain future. It also exhibits a transnational sense of space, bridging gaps between the local, the national and the diasporic world. This future-oriented sense of time and transnational sense of space are integrated and materialised through the garden. Altogether, it symbolises an imagined homecoming at 
both individual and national levels, articulating his desire to build a de-territorialised Chinese nation intertwined with his self-identification as a returned Overseas Chinese.

In summary, the Turtle Garden, built in combination of the Western notion of civic museums and Chinese poetics of gardening, represents a fascinating juxtaposition of a wide range of conflicting ideas, understandings and values - Communism and Confucian, traditional and modern, local and global, individual and national, rational and emotional, life and death. It materialises a postcolonial 'carnivalesque' space (Bakhtin 1984) where the prevailing revolutionary discourse of Chinese cultural heritage was questioned and suspended, and alternative imagining of Chinese identities and a diasporic representation of Chinese nation were articulated from the 'outside'.

\section{Conclusion}

The unprecedented thriving of huaqiao museums in the PRC draws our attention to the politics of representing diasporic subjects in China's museum spaces and the role of diasporic heritage in the CCP's nation-(re)building projects. In an attempt to address this, this article examined the museum outlook and practice of Tan Kah Kee with an analytical focus on the Turtle Garden. It suggests, firstly, the development of museum and heritage cannot be discussed in abstract and technical terms only. Rather, they have to be understood as both objective and subjective, rational and emotional, almost magically taking place in specific historical and political contexts in association with broader issues of territory, sovereignty, ethnicity, power, citizenship and nationhood. An icon of patriotism on the surface, Tan's motivation and practice of museum-building was in fact deeply embedded in his life experience as a diasporic Chinese, his encounter with (British) colonialism in Southeast Asia, his desire and despair about China's nation-building project, and the de-colonisation movement in postwar Asia. The Turtle 
Garden, conceptualised as postcolonial 'carnivalesque' space, symbolises Tan's last spiritual world in which he simultaneously engaged with soul-searching as an Overseas Chinese, imagined a modern, independent Chinese nation on the globe, and attempted to establish meaningful relationship between these two. Through innovative engagement with politically-charged and future-oriented museum practice, he sought painstakingly to figure out who he was, find a solution to China's political complications and articulate his vision of a modern Chinese nation from a diasporic perspective.

Secondly, the Turtle Garden materialises what can be called 'outside-in' heritage-making practised by diasporic subjects in the Chinese context. The garden 'was clearly more than an aesthetic game of complexity and contradiction; rather it was a compelling alternative, with its own special meanings, to the world of official responsibilities' (Jencks 2003, 217), and a vehicle to resist as well as compromise with difficult political realities that Tan and the returned Overseas Chinese faced in the 1950s China. This alternative heritage-making from outside the party-state's polity was significantly different from the Maoist revolutionary discourse that tended to politicise the representation of Chinese history and Chinese nation. It also poses new questions to the developing cultural heritage industry in the post-Mao China when the collaboration between state power and international authorities such as UNESCO is producing new forms of hegemony that continue to promote monolithic AHD. While a new wave of huaqiao museum construction is underway, the Turtle Garden provides us with an invaluable material and analytical lens to complicate the assumed heritage discourse often framed by a centralised and territorially-bounded viewpoint, discussed in scientific terms and governed by highly rigid top-down power structures. Furthermore, it offers a much-needed counter discourse to disentangle the contested and ever shifting 
relationship between diasporic subjects, cultural heritage and China's nation(re)building project in the global context.

\section{Acknowledgments}

The field trip conduced for research published in this article was funded by Universities' China Committee in London (UCCL). I am grateful to Mr. Huang Jikai, Ms. Lv Yongmei, Mr. Ding Jiongchun, Mr. Liu Xiaobin and Ms. Huang Jing for their assistance during my fieldwork in China. I would also like to thank Susan Ashley, Sybille Frank and the two anonymous reviewers for their comments that helped the revision of this paper.

\section{Endnotes}

1. Huaqiao is the Chinese equivalent to Overseas Chinese, referring to Chinese nationals living abroad. Despite the fact that a large number of Chinese living abroad today have become naturalised foreign citizens, official museums in the PRC still use the term huaqiao to designate them. In this paper, 'huaqiao', 'Overseas Chinese' and 'Chinese diaspora' are used interchangeably to encompass Chinese citizens living abroad and foreign nationals of Chinese descent. Similarly, the term 'diasporic' is used in this paper to refer to the experiences and subjectivities associated with transnational movement.

2. Tan Kah Kee is the name transcribed in the Wade-Giles system based on pronunciation in Southern Fujian dialect. It is also transcribed as Chen Jiageng in pinyin system and widely used in mainland China.

3. Tan was the initiator and one of the chief donors for the construction of the Overseas Chinese Museum, and the sole funder of the Turtle Garden. Tan masterminded the design, construction and curating of these two museums, in particular the Turtle Garden (Ding 1999, 14-18; Ouyang 2008, 7-8).

4. Tan visited a number of colonial museums during his trips to China in 1949 and 1950. These include those built by the Russians and Japanese in Manchuria, and the Guangzhi Yuan (Academy of Broad Knowledge) built by British Baptist missionaries in Jinan, Shandong province. He was particularly impressed by the wide range of subjects displayed in Guangzhi Yuan and the exhibiting techniques it used. See Tan (1950, 17, $61)$.

5. Tan was general designer and chief engineer of the whole project, giving builders and artisans detailed and often on-site instructions. He had the blue print in his mind and directed the construction with his walking stick (author's interview with Mr. Liu, the deputy curator of Tan Kah Kee Memorial Hall, 7 August 2013). 
6. The local villagers covered the stone carvings with thick mud to protect them from being discovered and damaged by the Red Guards. Mao's calligraphy inscribed on the Jimei Liberation Monument also protected the garden as any attempts to destroy it could be interpreted as disrespectful of Mao (author's interview with Mr. Chen, museum personnel from the exhibition department of the Tan Kah Kee Memorial Resort, 8 August 2013).

7. Tan Kah Kee Memorial Resort Tourist Guide, Jimei, 2013.

\section{Notes on contributor}

Cangbai Wang is a Senior Lecturer of Contemporary Chinese Studies at University of Westminster, UK. His research interests are the history and identities of returned Overseas Chinese in the PRC, professional migrants in postcolonial Hong Kong and more recently the interaction between mobilities and materialities in the diasporic Chinese world. $\mathrm{He}$ is currently working on a book project about museum representations of the Overseas Chinese in the PRC.

\section{References}

Bakhtin, Mikhail. 1984. Rabelais and His World. Translated by Helene Iswolsky. Bloomington: Indiana University Press.

Bakhtin, Mikhail. 1999. Problems of Dostoevsky's Poetics. Edited and translated by Caryl Emerson. Minneapolis: University of Minnesota Press.

Calvert, Dave. 2012. "Carnival of the Mundane: Red Oktober at England's National Tramway Museum". In Performance Studies International, 27th June - 1st July 2012, Leeds University, UK (Unpublished).

Chambers, Iain, Alessandra De Angelis, Celeste Ianniciello, Mariangela Orabona and Michaela Quadraro, eds. 2014. The Postcolonial Museum: the Arts of Memory and the Pressures of History. Surrey: Ashgate.

Chen, Congzhou. 2002. Shuo Yuan [On Chinese Gardens]. Jinan: Shandong Huabao Chubanshe, Tongji Daxue Chubanshe.

Chen, Gongcun and Hong Yonghong. 2003. Chen Jiageng Xinzhuang [ A New Biography of Tan Kah Kee. Singapore: Tan Kah Kee International Society.

Denton, Kirk A. 2014. Exhibiting the Past: Historical Memory and the Politics of Museums in Postsocialist China. Honolulu: University of Hawaii’s Press. 
Dickinson, Greg, Brian L. Ott and Aoki Eric. 2005. "Memory and Myth at the Buffalo Bill Museum.” Western Journal of Communication 69 (2): 85-108.

Ding, Jiongcun. ed. 1999. Huaqiao Bowuyuan Sishi Zhounian Jinian Tekan [Commemorative Issue for the $40^{\text {th }}$ Anniversary of the Overseas Chinese Museum]. Xiamen: the Overseas Chinese Museum.

Draguhn, Werner and David S. Goodman. eds. 2002. China's Communist Revolutions: Fifty Years of the People's Republic of China. London: RoutledgeCurzon.

Fang, Xiaofeng, 2010. The Great Chinese Gardens: History, Concepts, Techniques. Harrow: CYPI press.

Hall, Stuart. 1996. "When was 'the Post-colonial'? Thinking at the Limit." In The Postcolonial Question: Common Skies, Divided Horizons, edited by Iain Chambers and Lidia Curti, 242-260. London: Routledge.

Huang, You. 2014. "Chen Jiageng de Shehui Jiaoyu Sixiang yu Bowuguan” [Tan Kah Kee's Ideas on Public Education and the Construction of Museums], in Zhongguo Huaqiao Lishi Bowuguan Kaiguan Jinian Tekan[Commemorative Issue for the Opening of National History Museum of the Overseas Chinese], edited by Li Zhuobin, 47-51. Beijing: Zhongguo Huaqiao Chubanshe.

Jencks, Charles. 2003. "Meanings of the Chinese Garden." In The Chinese Garden: History, Art and Architecture, written by Maggie Keswick, revised by Alison Hardie, contribution and conclusion by Charles Jencks, 208-217. Cambridge, Mass.: Harvard University Press.

Karl, Rebecca E. 2010. Mao Zedong and China in the Twentieth-century World: a Concise History. Durham: Duke University Press.

Keswick, Maggie. 1988. "Forward.” In Ji, Cheng, The Craft of Gardens, Translated by Alison Hardie, with a foreword by Maggie Keswick, 15-28. New Haven: Yale University Press.

Keswick, Maggie, 2003. The Chinese Garden: History, Art and Architecture. revised by Alison Hardie, contribution and conclusion by Charles Jencks. Cambridge, Mass.: Harvard University Press.

Knell, Simon J, Peter Aronsson, Arne Bugge Amundsen, Amy Jane Barnes, Stuart Burch, Jennifer Carter, Viviane Gosselin, Sarah A. Hughes and Alan Kirwan, eds. 2011. National Museums: New Studies From Around the World. London and New York: Routledge. 
Ji, Cheng. 1988. The Craft of Gardens, Translated by Alison Hardie, with a foreword by Maggie Keswick, 15-28. New Haven: Yale University Press.

Liu, Xiaobin. 2014. “Chen Jiageng de Bowuguan Sixiang” [Tan Kah Kee’s Museum Thought]. Zhongguo Bowuguan [Chinese Museum] (1): 102-106.

Lu, Tracey Lie Dan. 2014. Museums in China: Power, Politics and Identities. London: Routledge.

McTavish, Lianne. 1998. "Shopping in the Museum? Consumer Spaces and the Redefinition of the Louvre." Cultural Studies 12 (2): 168-192.

NPPCC's Research Committee of Cultural and Historical Archives, All-China Federation of Returned Overseas Chinese and Fujian Provincial PCC. eds. 1984. Huiyi Chen Jiageng : Jinian Chen Jiageng Xiansheng Danchen Yibai Yishi Zhounian [In Memory of Tan Kah Kee: Commemorating the 110th Anniversary of the Birth of Tan Kah Kee]. Beijing: Wenshiziliao Chubanshe.

Ouyang, Jian. ed. 2008. Chen Jiageng Jinian Shengdi [The Tan Kah Kee Memorial Shrine]. Beijing: Zhongguo Sheying Chubanshe.

Peterson, Glen. 2012. Overseas Chinese in the People's Republic of China. London: Routledge.

Simon, Roger L. and Susan L. T. Ashley. 2010. "Introduction: Heritage and Practice of Public Formation." International Journal of Heritage Studies 16 (4-5): 247-254.

Smith, Laurajane. 2006. The Uses of Heritage. London: Routledge.

Tan, Jiang. 2007. "Chen Jiageng Shoujian Huaqiao Bowuguang” [Tan Kah Kee Initiated the Overseas Chinese Museum Construction]. Renmin Ribao [People's Daily (overseas edition)], July 24.

Tan, Kah Kee. 1950. Xin Zhongguo Guanguang Ji [Records of Travelling in the New China]. Hong Kong: Singaporean Southseas China Relief Fund Union.

Tan, Kah Kee. 1956. "Chuangban Huaqiao Bowuyuan Yuanqi” [Some Initial Ideas behind the Calling for Constructing the Overseas Chinese Museum], in Commemorative Issue for the $40^{\text {th }}$ Anniversary of the Overseas Chinese Museum, edited by Ding Jiongchun,1999, 6-7. Xiamen: Overseas Chinese Museum.

Tan, Kah Kee. 1993. Nanqiao Huiyilu [The Memoirs of an Overseas Chinese of the Southern Ocean]. Jimei: Tan Kah Kee Research Society (reprinted version). 
Walton, John K. 1998. 'Popular Entertainment and Public Order: The Blackpool Carnivals of 1923-24.' Northern History 34: 170-88.

Webb, Darren. 2005. "Bakhtin at the Seaside: Utopia, Modernity and the Carnivalesque." Theory, Culture \& Society 22(3): 121-138.

Wang, Cangbai. 2013. "Guiqiao as Political Subjects in the Making of the People's Republic of China 1949-1979.” In Return: Nationalizing Transnational Mobility in Asia, edited by Xiang, Biao, Brenda Yeoh and Mika Toyota, 63-82. Durham: Duke University Press.

Wang, Zengbing and Yu Gang. 1981. Chen Jiageng Xingxue Ji [A history of Tan Kah Kee's Establishment of Schools]. Fuzhou: Fujian Education Publisher.

Yong, Ching-Fatt. 1987. Tan Kah Kee: The Making of an Overseas Chinese Legend. Singapore: Oxford University Press. 